\title{
ANALISIS FAKTOR LINGKUNGAN BELAJAR YANG MEMPENGARUHI HASIL BELAJAR SISWA
}

\author{
Ayu Yarmayani ${ }^{1}$, Diliza Afrila ${ }^{2}$
}

\begin{abstract}
This research was aimed to find out (1) Description of X class learning environment at SMA Negeri 8 Jambi City, and (2) Factors of learning environment which affect students learning outcomes of X Class at SMA Negeri 8 Jambi City. The type of this research was quantitative descriptive research. The population in this research was 602 students. Technique used to take sample in this research was random sampling, selected 100 students as sample of the research. Technique to collect data in this research was spreading the questionnaire to the research respondents and interviews. Technique to analyze data in this research was factor analysis by using program of SPSS Version 16. The result of research indicated that (1) learning environment variables were in enough category with average 3,91 and Response Achievement Level (TCR) equal to 78,26, and 2) There were 10 (ten) dominant factors which affected students learning environment, namely (a) Factor 1 which was given teaching method, which consisted of statement items F6.1, F6.2, F6.3, F7.2, and F7. 4, (b) Factor 2 which was given the identity of the relation between the family members, which consisted of the statement items F2.2, F2.3, and F14.3, (c) Factor 3 which was given the identity of the community life form, F9.3, F10.1, F14.1 and F14.2, (d) Factor 4 identified the learning instrument, which consisted of the statement items F9.2, F10.2, F10.3, and F12.2, (e) Factor 5 which was given the identity of the parent's understanding, which consisted of the statement items F3.1, F5.1, F5.2, and F8.4, (f) Factor 6 which was given the identity of the home atmosphere, which consisted of statement items F1.3 and F3.2 (g) Factor 7 which identified teacher relation with student, consisted of statement items F7.1, F7.3, and F12.1, (h) Factor 8 identified the school discipline, consisted of statement items F9.1, and F9.3, (i) Factor 9 identified the friends' interactions consisted of statement items F8.2 and F13.2, and (j) Factors 10 which was given the identity of the parents' economic status, which consisted of statement items F3.3 and F4.1.
\end{abstract}

Keyword: Factor Analysis, Learning Environment, Learning Outcomes

\footnotetext{
${ }^{1}$ Dosen Pendidikan Matematika Universitas Batanghari

${ }^{2}$ Dosen Pendidikan Ekonomi Universitas Batanghari
} 


\section{PENDAHULUAN}

Pendidikan merupakan salah satu kebutuhan mendasar yang harus dimiliki oleh setiap manusia. Tanpa pendidikan manusia tidak dapat meningkatkan taraf hidupnya. Dengan kata lain, pendidikan merupakan salah satu upaya untuk meningkatkan kualitas Sumber Daya Manusia (SDM). SDM yang berkualitas sangat penting dalam melaksanakan pembangunan berkelanjutan, baik fisik maupun non fisik. Oleh karena itu, perluasan dan pemerataan kesempatan belajar merupakan salah satu prioritas utama pemerintah.UU RI No. 20 Tahun 2003 tentang tentang Sistem Pendidikan Nasional Pasal 1 menyatakan bahwa:

Pendidikan adalah usaha sadar
dan terencana untuk
mewujudkan suasana belajar
dan proses pembelajaran agar
peserta didik secara aktif
mengembangkan potensi dirinya
untuk memiliki kekuatan
spiritual keagamaan,
pengendalian diri, kecerdasan,
akhlak mulia serta keterampilan
yang diperlukan dirinya,
masyarakat, bangsa, dan negara.

$$
\text { Pernyataan di atas }
$$

menyiratkan makna bahwa dengan pendidikan diharapkan manusia dapat mengembangkan potensi yang ada pada dirinya, sehingga menimbulkan perubahan yang memungkinkannya berperan secara aktif dalam masyarakat. Sekolah sebagai salah satu lembaga pendidikan formal memiliki peranan penting dalam pengembangan dan pembinaan potensi yang dimiliki oleh siswa. Oleh karena itu, sekolah dirancang untuk menyiapkan peserta didik yang memiliki kemampuan, keterampilan, dan keahlian, sehingga lulusannya siap memasuki dunia kerja dan mampu mengembangkan sikap profesional dibidang pekerjaannya.

Upaya peningkatan mutu pendidikan, khususnya pendidikan di sekolah tidak terlepas dari masalah hasil belajar yang dicapai oleh siswa. Untuk mencapai hasil belajar yang maksimal diperlukan usaha yang sungguh-sungguh dari peserta didik maupun guru sebagai pendidik. Rendahnya hasil belajar siswa salah satunya dipengaruhi oleh faktor lingkungan belajar. Siswa dalam proses pembelajaran memerlukan konsentrasi yang tinggi, penerapan, dan penerimaan informasi. Oleh karena itu, lingkungan belajar yang kondusif perlu diwujudkan, sehingga siswa merasa nyaman dan belajar dengan konsentrasi yang tinggi. Menurut Yamin (2011:297) "Lingkungan belajar adalah segala sesuatu yang terdapat di tempat belajar".

Pada hakekatnya, lingkungan belajar yang mempengaruhi hasil belajar siswa dapat diklasifikasikan atas 3 (tiga), yaitu lingkungan keluarga, lingkungan sekolah, dan lingkungan masyarakat. Ketiga lingkungan belajar tersebut harus saling bersinergi atau melengkapi, sehingga tercapai peningkatan hasil belajar siswa.

Lingkungan keluarga adalah tempat pendidikan pertama dan pendidikan prasekolah. Oleh karena itu, lingkungan keluarga sebagai wahana sosialisasi awal sebelum pendidikan dasar dikembangkan agar lebih mampu meletakkan landasan dan pembentukan watak serta 
kepribadian. Lingkungan keluarga bertanggungjawab dalam pengembangan sifat, pengetahuan, keterampilan, dan daya cipta. Hal ini dikarenakan keluarga adalah pihak yang paling awal memberikan layanan interaksi kepada anak, seperti dalam perilaku seorang ibu menyusui anaknya, menyayangi, memandikan, memberikan makan, dan memberi perhatian kepada anak. Dengan kata lain, lingkungan keluarga mempunyai andil dalam pendidikan anak. Berhasil atau tidaknya pendidikan anak tergantung kepada peran lingkungan keluarga.

Berdasarkan pengamatan penulis di lapangan diketahui bahwa lingkungan keluarga siswa masih ada yang belum berperan secara optimal. Hal ini terbukti dari masih adanya orang tua yang belum memberikan perhatian terhadap belajar siswa, masih ada siswa yang belum memiliki perlengkapan belajar yang lengkap, dan masih kurangnya intensitas komunikasi antara orang tua dan siswa.

Selain lingkungan keluarga, lingkungan sekolah juga berpengaruh terhadap keberhasilan siswa dalam proses pembelajaran. Kenyataan yang penulis temui di lapangan terlihat bahwa guru dalam proses pembelajaran masih cendrung teacher centered, masih ada guru yang belum menggunakan media dalam proses pembelajaran, interaksi antara guru dan siswa dalam proses pembelajaran masih kurang, kemampuan guru dalam pengelolaan kelas masih kurang, dan guru masih jarang memberikan penguatan dalam proses pembelajaran. Selanjutnya, lingkungan masyarakat disekitar siswa juga mempunyai andil terhadap pencapaian hasil belajar. Masih ada siswa yang belum selektif dalam memilih teman. Siswa yang bergaul dengan teman yang malas belajar maka akan ikut-ikutan malas belajar dan masih ada lingkungan masyarakat disekitar tempat tinggal siswa yang memiliki kebiasaan yang kurang baik, sehingga mengganggu kegiatan belajar siswa.

Mariyana, dkk (2010:16) mengemukakan bahwa "Lingkungan adalah suatu tempat atau suasana (keadaan) yang dapat mempengaruhi pertumbuhan dan perkembangan seseorang". Sedangkan, menurut Aini \& Taman, (2012)

"Lingkungan merupakan sesuatu yang mengelilingi individu di dalam hidupnya, baik dalam bentuk lingkungan fisik seperti orang tua, rumah, kawan bermain, dan masyarakat sekitar maupun dalam bentuk lingkungan psikologis seperti perasaan-perasaan yang dialami, cita-cita, persoalan-persoalan yang dihadapi, dan sebagainya".

Dengan demikian, dapat disimpulkan bahwa lingkungan yang mempengaruhi perkembangan seseorang tidak hanya lingkungan fisik saja, tetapi juga lingkungan psikologis.

Hamalik

mengemukakan bahwa "Lingkungan adalah sesuatu yang ada di alam sekitar yang memiliki makna dan atau pengaruh tertentu kepada individu". Sedangkan, Sartain (dalam Dalyono, 2009:132) mengemukakan bahwa "Lingkungan (environment) adalah semua kondisi-kondisi dalam dunia ini yang dalam cara-cara tertentu mempengaruhi tingkah laku kita, pertumbuhan, perkembangan atau life 
processes kita kecuali gen-gen, dan bahkan gen-gen dapat pula dipandang sebagai menyiapkan lingkungan (to provide environment) bagi gen yang lain". Selanjutnya, Sartain mengemukakan bahwa lingkungan dapat diklasifikasikan atas 3 (tiga), yaitu:

1. Lingkungan alam atau luar (external or physical environment), yaitu segala sesuatu yang ada dalam dunia ini yang bukan manusia seperti rumah, tumbuh-tumbuhan, air, iklim, dan hewan.

2. Lingkungan dalam (internal environment), yaitu segala sesuatu yang ada dalam diri kita.

3. Lingkungan sosial (social environment), yaitu semua orang atau manusia lain yang mempengaruhi kita. Pengaruh lingkungan sosial itu ada yang kita terima secara langsung dan ada yang tidak langsung, melalui pergaulan sehari-hari dengan orang lain, keluarga, temanteman, kawan sekolah, dan teman sepekerjaan.

Belajar pada hakikatnya adalah suatu interaksi antara individu dan lingkungan. Lingkungan menyediakan rangsangan (stimulus) terhadap individu dan sebaliknya individu memberikan respon terhadap lingkungan. Dalam proses interaksi tersebut dapat terjadi perubahan pada diri individu berupa tingkah laku.

Lingkungan (environtment) sebagai dasar proses pembelajaran adalah faktor kondisional yang mempengaruhi tingkah laku individu dan merupakan faktor belajar yang penting. Menurut Hamalik (2013:196) lingkungan belajar terdiri atas:
1. Lingkungan sosial adalah lingkungan masyarakat baik kelompok besar atau kelompok kecil.

2. Lingkungan personal meliputi individu-individu sebagai suatu pribadi berpengaruh terhadap individu pribadi yang lain.

3. Lingkungan alam (fisik) meliputi Sumber Daya Alam (SDA) yang dapat diberdayakan sebagai sumber belajar.

4. Lingkungan kultural mencakup hasil budaya dan teknologi yang dapat dijadikan sumber belajar dan dapat menjadi faktor-faktor pendukung pembelajaran. Dalam konteks ini termasuk sistem nilai, norma, dan adat kebiasaan.

Menurut Slameto (2010:6072) lingkungan yang mempengaruhi belajar dapat dibedakan atas 3 (tiga) bentuk, yaitu:

1. Lingkungan Keluarga Hasbullah

menjelaskan bahwa "Lingkungan keluarga adalah lingkungan pendidikan yang pertama, karena dalam keluarga inilah anak pertamatama mendapatkan didikan dan bimbingan. Dikatakan lingkungan yang utama karena sebagian besar dari kehidupan anak adalah di dalam keluarga, sehingga pendidikan yang paling banyak diterima oleh anak adalah dalam keluarga". Dengan demikian, orang yang pertama dan utama yang bertanggungjawab terhadap kelangsungan hidup dan pendidikan anak adalah orang tua.

Selanjutnya, Hasbullah (2013:44-45) mengemukakan bahwa dasar-dasar tanggung jawab orang tua terhadap pendidikan anaknya adalah sebagai berikut: 
a. Adanya motivasi atau dorongan cinta kasih yang menjiwai hubungan orang tua dan anak. Kasih sayang orang tua yang ikhlas dan murni akan mendorong sikap dan tindakan rela menerima tanggungjawab untuk mengorbankan hidupnya dalam memberikan pertolongan kepada anaknya.

b. Pemberian motivasi kewajiban moral sebagai konsekuensi kedudukan orang tua terhadap keturunannya. Adanya tanggungjawab moral ini meliputi nilai-nilai agama atau nilai-nilai spiritual.

c. Tanggungjawab sosial adalah bagian dari keluarga yang pada gilirannya akan menjadi tanggungjawab masyarakat, bangsa, dan negara. Tanggungjawab sosial itu merupakan perwujudan kesadaran tanggungjawab kekeluargaan yang dibina oleh darah, keturunan, dan kesatuan keyakinan.

d. Memelihara dan membesarkan anaknya. Tanggungjawab ini merupakan dorongan alami untuk dilaksanakan, karena anak memerlukan makan, minum, dan perawatan, agar ia dapat hidup secara berkelanjutan. Disamping itu, orang tua bertanggungjawab dalam hal melindungi dan menjamin kesehatan anaknya, baik secara jasmaniah maupun rohaniah dari berbagai gangguan penyakit atau bahaya lingkungan yang dapat membahayakan diri anak tersebut.

e. Memberikan pendidikan dengan berbagai ilmu pengetahuan dan keterampilan yang berguna bagi kehidupan anak kelak, sehingga apabila ia telah dewasa akan mampu mandiri.

Berdasarkan uraian di atas, maka dapat ditarik kesimpulan bahwa lingkungan keluarga merupakan lingkungan pendidikan pertama dan utama bagi setiap anak. Oleh karena itu, keberhasilan pendidikan seorang anak merupakan tanggungjawab keluarga (orang tua). Tanggungjawab orang tua tersebut tidak hanya berkaitan dengan pemenuhan kebutuhan anak yang bersifat materi, tetapi juga nonmateri.

2. Lingkungan Sekolah

Menurut Dalyono

(2009:131)

"Sekolah merupakan satu faktor yang turut mempengaruhi pertumbuhan dan perkembangan anak terutama untuk kecerdasannya". Anak yang tidak pernah sekolah akan ketinggalan dalam berbagai hal. Sekolah sangat berperan dalam meningkatkan pola pikir anak, karena di sekolah mereka dapat belajar bermacam-macam ilmu pengetahuan. Tinggi rendahnya pendidikan dan jenis sekolahnya turut menentukan pola pikir serta kepribadian anak.

Pada dasarnya, pendidikan di sekolah merupakan bagian dari pendidikan dalam keluarga, yang sekaligus juga merupakan lanjutan dari pendidikan dalam keluarga. Peranan sekolah sebagai lembaga yang membantu lingkungan keluarga, maka sekolah bertugas mendidik dan mengajar serta memperbaiki dan memperhalus tingkah laku anak didik yang dibawa dari keluarganya. Menurut Hasbullah (2013:49) peranan sekolah melalui kurikulum adalah sebagai berikut:

a. Anak didik belajar bergaul sesama anak didik, antara guru 
dengan anak didik, dan antara anak didik dengan orang yang bukan guru (karyawan).

b. Anak didik belajar mentaati peraturan-peraturan sekolah.

c. Mempersiapkan anak didik untuk menjadi anggota masyarakat yang berguna bagi agama, bangsa, dan negara.

Bentuk

kecerdasan

(pengertian), sikap, dan minat sebagai bagian dari pembentukan kepribadian dilaksanakan oleh sekolah. Kenyataan ini menunjukkan betapa penting dan besarnya pengaruh dari sekolah. Menurut Hasbullah (2013:50-51) fungsi sekolah adalah sebagai berikut:

a. Mengembangkan kecerdasan pikiran dan memberikan pengetahuan.

b. Spesialisasi

Sekolah mempunyai fungsi sebagai lembaga sosial yang spesialisasinya dalam bidang pendidikan dan pengajaran.

c. Efisiensi

Adanya sekolah sebagai lembaga sosial yang berspesialisasi dibidang pendidikan dan pengajaran, maka pelaksanaan pendidikan dan pengajaran dalam masyarakat menjadi lebih efisisen dengan alasan sebagai berikut:

1) Seumpama tidak ada sekolah dan pekerjaan mendidik hanya harus dipikul oleh keluarga, maka hal ini tidak efisien karena orang tua tidak mampu melaksanakan pendidikan dimaksud.

2) Pendidikan sekolah dilaksanakan dalam program yang tertentu dan sistematis.

3) Di sekolah dapat dididik sejumlah besar anak secara sekaligus. d. Sosialisasi

Sekolah mempunyai peranan yang penting di dalam proses sosialisasi, yaitu proses membantu perkembangan individu menjadi makhluk sosial, makhluk yang dapat beradaptasi dengan baik di masyarakat. Karena, bagaimanapun pada akhirnya dia berada di masyarakat.

e. Konservasi dan transmisi cultural Fungsi lain dari sekolah adalah memilihara warisan budaya yang hidup dalam masyarakat dengan jalan menyampaikan warisan kebudayaan tadi (transmisi kultural) kepada generasi muda, dalam hal ini tentunya adalah anak didik.

f. Transisi dari rumah ke masyarakat Ketika berada di keluarga, kehidupan anak serba menggantungkan diri kepada orang tua, maka memasuki sekolah di mana ia mendapat kesempatan untuk melatih berdiri sendiri dan tanggung jawab sebagai persiapan sebelum ke masyarakat.

Berdasarkan penjelasan di atas, maka dapat ditarik kesimpulan bahwa lingkungan sekolah merupakan lingkungan pendidikan kedua bagi anak setelah lingkungan keluarga. Melalui sekolah, anak lebih dapat menggali dan mengembangkan potensi yang ada pada dirinya. Karena, di lingkungan sekolah ada tenaga pendidik (guru) yang memberikan pengetahuan, yang tidak mampu diberikan oleh orang tua.

3. Lingkungan Masyarakat

Masyarakat adalah lingkungan tempat tinggal anak. Menurut Sadulloh (2010:204) "Masyarakat 
mencakup sekelompok orang yang berinteraksi antar sesamanya, saling tergantung dan terikat oleh nilai dan norma yang dipenuhi bersama, serta pada umumnya bertempat tinggal di wilayah tertentu, dan ada kalanya mereka memiliki hubungan darah atau memiliki kepentingan bersama". Sedangkan, menurut Hasbullah (2013:55) "Masyarakat adalah sekumpulan orang yang menempati suatu daerah, diikat oleh pengalamanpengalaman yang sama, memiliki sejumlah persesuaian dan sadar akan kesatuannya, serta dapat bertindak bersama untuk mencukupi krisis kehidupannya”. Dalam konteks pendidikan, masyarakat merupakan lingkungan ketiga setelah keluarga dan sekolah.

Lingkungan belajar merupakan salah satu faktor ekstern yang mempengaruhi belajar. Menurut Slameto (2010:60-72) lingkungan yang mempengaruhi belajar dapat dibedakan atas 3 (tiga), yaitu:

1. Lingkungan keluarga, yang terdiri atas: (a) Cara orang tua mendidik; (b) Relasi antaranggota keluarga; (c) Suasana rumah; (d) Keadaan ekonomi keluarga dan (e) Pengertian orang tua.

2. Lingkungan sekolah, yang terdiri atas: (a) Metode mengajar; (b) Relasi guru dengan siswa; (c) Relasi siswa dengan siswa; (d) Disiplin sekolah; (e) Alat pelajaran; (f) Waktu sekolah; (g) Keadaan gedung; (h) Metode belajar dan (i) Tugas rumah.

3. Lingkungan masyarakat, yang terdiri atas: (a) Kegiatan siswa dalam masyarakat; (b) Mass media; (c) Teman bergaul dan (d) Bentuk kehidupan masyarakat.

\section{METODE PENELITIAN}

Penelitian ini termasuk jenis penelitian deskriptif dengan pendekatan kuantitatif. Menurut Arikunto (2014:3) "Penelitian deskriptif adalah penelitian yang dimaksudkan untuk menyelidiki keadaan, kondisi atau hal-hal lain yang sudah disebutkan, yang hasilnya dipaparkan dalam bentuk laporan penelitian". Riduwan (2013:54) mengemukakan bahwa "Populasi merupakan objek atau subjek yang berada pada suatu wilayah dan memenuhi syarat-syarat tertentu berkaitan dengan masalah penelitian". Adapun populasi penelitian ini adalah siswa kelas X Di SMA Negeri 8 Kota Jambi, dengan rincian sebagai berikut:

Tabel 1. Siswa Kelas X di SMA Negeri 8 Kota Jambi

\begin{tabular}{|c|l|c|}
\hline No. & \multicolumn{1}{|c|}{ Kelas } & Jumlah \\
\hline 1. & X IPS 1 & 40 \\
\hline 2. & X IPS 2 & 40 \\
\hline 3. & X IPS 3 & 39 \\
\hline 4. & X IPS 4 & 39 \\
\hline 5. & X IPS 5 & 39 \\
\hline 6. & X IPS 6 & 39 \\
\hline 7. & X IPS 7 & 39 \\
\hline 8. & X IPS 8 & 38 \\
\hline 9. & X IPA 1 & 36 \\
\hline 10. & X IPA 2 & 35 \\
\hline 11. & X IPA 3 & 36 \\
\hline 12. & X IPA 4 & 37 \\
\hline 13. & X IPA 5 & 37 \\
\hline 14. & X IPA 6 & 36 \\
\hline 15. & X IPA 7 & 36 \\
\hline 16. & X IPA 8 & 36 \\
\hline \multicolumn{2}{|c|}{ Jumlah } & $\mathbf{6 0 2}$ \\
\hline Sumber: TU SMA Negeri 8 Kota
\end{tabular}

Jambi, 2017

Analisis data merupakan kegiatan setelah data dari seluruh responden atau sumber data lain terkumpul. Teknis analisis data pada 
penelitian kuantitatif menggunakan statistik.

1. Analisis Deskriptif

Analisis deskriptif bertujuan untuk memberikan gambaran umum tentang variabel yang diteliti dengan cara menyajikan data ke dalam tabel distribusi frekuensi. Adapun variabel penelitian yang dideskripsikan adalah lingkungan belajar siswa kelas X. Setelah data disajikan ke dalam tabel distribusi frekuensi maka dilakukan analisis persentase dan interpretasi terhadap hasil analisis.

2. Analisis Faktor

Menurut Idris

(2010:158)

"Analisis faktor merupakan jenis analisis yang digunakan untuk mengenali dimensi-dimensi pokok atau keteraturan dari sebuah fenomena". Tujuan utama analisis faktor adalah untuk meringkas kandungan informasi variabel dalam jumlah yang besar menjadi sejumlah faktor yang lebih kecil.

3. Uji Hipotesis

\section{a. Uji KMO (Kaiser Meyer Olkin)}

Uji KMO digunakan untuk meneliti ketepatan analisis faktor. Nilai yang tinggi antara $0,5-1,0$ berarti analisis faktor dikatakan tepat. Sebaliknya, nilai kurang dari 0,5 berarti analisis faktor dikatakan tidak tepat. Selain itu, Uji KMO juga bertujuan untuk mengetahui apakah semua data yang telah terambil telah cukup untuk difaktorkan. Apabila nilai $\mathrm{KMO}>0,5$ maka jumlah data cukup untuk difaktorkan, dan sebaliknya apabila nilai $\mathrm{KMO}<0,5$ maka jumlah data tidak cukup untuk difaktorkan.

b. Uji Bartlett's Sphericity Test Uji Bartlett's Sphericity Test adalah uji yang digunakan untuk menguji hipotesis bahwa variabel tidak berkorelasi di dalam populasi. Dengan kata lain, matrik korelasi populasi adalah matrik identity. Dimana, setiap variabel berkorelasi dengan dirinya sendiri secara sempurna dengan $(\mathrm{r}=1)$ akan tetapi sama sekali tidak berkorelasi dengan lainnya ( $\mathrm{r}$ $=0$ ).

\section{HASIL DAN PEMBAHASAN}

\section{A. Faktor 1: Metode Mengajar}

Berdasarkan hasil analisis faktor, maka diperoleh faktor 1 yang selanjutnya diberi identitas metode mengajar. Faktor yang terbentuk dari pernyataan-pernyataan pendukung dominan yang membentuk faktor 1 tergambar pada tabel sebagai berikut:

Tabel 3. Hasil Analisis Faktor 1

\begin{tabular}{|c|c|l|c|}
\hline $\begin{array}{c}\text { N } \\
\text { o }\end{array}$ & Kode & Pernyataan & $\begin{array}{c}\text { Koefisien } \\
\text { Faktor }\end{array}$ \\
\hline 1. & F6.1 & $\begin{array}{l}\text { Guru } \\
\text { menggunakan } \\
\text { metode } \\
\text { pembelajaran } \\
\text { yang bervariasi } \\
\text { dan } \\
\text { menyenangkan }\end{array}$ & 0,688 \\
\hline 2. & F6.2 & $\begin{array}{l}\text { Guru } \\
\text { menggunakan } \\
\text { media dalam } \\
\text { proses } \\
\text { pembelajaran }\end{array}$ & 0,770 \\
\hline 3. & F6.3 & $\begin{array}{l}\text { Guru menguasai } \\
\text { materi pelajaran }\end{array}$ \\
\hline
\end{tabular}




\begin{tabular}{|l|l|l|l|}
\hline & & dengan baik & \\
\hline 4. & F7.2 & $\begin{array}{l}\text { Guru } \\
\text { menciptakan } \\
\text { suasana belajar } \\
\text { yang } \\
\text { menyenangkan di } \\
\text { kelas }\end{array}$ & \\
\hline 5. & F7.4 & $\begin{array}{l}\text { Ketika saya } \\
\text { mengalami } \\
\text { kesulitan belajar } \\
\text { di sekolah, guru } \\
\text { membantu saya }\end{array}$ \\
\hline
\end{tabular}

Berdasarkan tabel 3 di atas diketahui bahwa faktor 1 yang terbentuk terdiri dari 5 (lima) item pernyataan. Dimana, item pernyataan guru menggunakan media dalam proses pembelajaran memiliki nilai koefisien faktor tertinggi, yaitu 0,770. Sedangkan, item pernyataan guru menguasai materi pelajaran dengan baik memiliki nilai koefisien faktor terendah, yaitu 0,645.

\section{B. Faktor 2: Relasi Antara Anggota Keluarga}

Berdasarkan hasil analisis faktor, maka diperoleh faktor 2 yang selanjutnya diberi identitas relasi antara anggota keluarga. Faktor yang terbentuk dari pernyataan-pernyataan pendukung dominan yang membentuk faktor 2 tergambar pada tabel sebagai berikut:

Tabel 4. Hasil Analisis Faktor 2

\begin{tabular}{|c|l|l|r|}
\hline $\begin{array}{c}\mathbf{N} \\
\mathbf{o}\end{array}$ & Kode & Pernyataan & $\begin{array}{c}\text { Koefisien } \\
\text { Faktor }\end{array}$ \\
\hline 1. & F2.2 & $\begin{array}{l}\text { Orang tua } \\
\text { menyelesaikan } \\
\text { permasalahan } \\
\text { yang terjadi di } \\
\text { rumah secara } \\
\text { musyawarah }\end{array}$ & \\
\hline 2. & F2.3 & $\begin{array}{l}\text { Saya menjalin } \\
\text { Saya }\end{array}$ & 0,631 \\
\hline
\end{tabular}

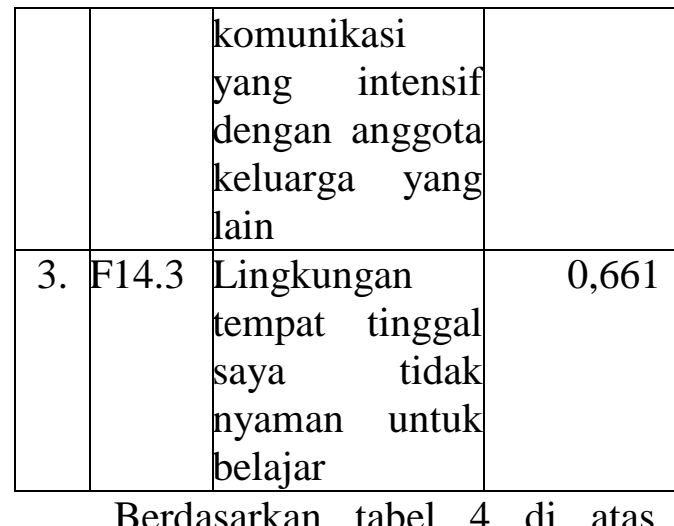

Berdasarkan tabel 4 di atas diketahui bahwa faktor 2 yang terbentuk terdiri dari 3 (tiga) item pernyataan. Dimana, item pernyataan orang tua menyelesaikan permasalahan yang terjadi di rumah secara musyawarah memiliki nilai koefisien faktor tertinggi, yaitu 0,725. Sedangkan, item pernyataan saya menjalin komunikasi yang intensif dengan anggota keluarga yang lain memiliki nilai koefisien faktor terendah, yaitu 0,631 .

\section{Faktor 3: Bentuk Kehidupan Masyarakat}

Berdasarkan hasil analisis faktor, maka diperoleh faktor 3 yang selanjutnya diberi identitas bentuk kehidupan masyarakat. Faktor yang terbentuk dari pernyataan-pernyataan pendukung dominan yang membentuk faktor 3 tergambar pada tabel sebagai berikut:

Tabel 5. Hasil Analisis Faktor 3

\begin{tabular}{|c|l|l|c|}
\hline $\begin{array}{c}\text { N } \\
\mathbf{0}\end{array}$ & Kode & Pernyataan & $\begin{array}{c}\text { Koefisien } \\
\text { Faktor }\end{array}$ \\
\hline 1. & F8.3 & $\begin{array}{l}\text { Saya belajar } \\
\text { kelompok di } \\
\text { rumah teman } \\
\text { setelah pulang } \\
\text { sekolah }\end{array}$ & 0,572 \\
\hline 2. & F10.1 & $\begin{array}{l}\text { Saya } \\
\text { memanfaatkan } \\
\text { perpustakaan }\end{array}$ & 0,737 \\
\hline
\end{tabular}




\begin{tabular}{|c|c|c|c|}
\hline & & $\begin{array}{l}\text { untuk } \\
\text { membaca buku } \\
\text { pada saat jam } \\
\text { pelajaran } \\
\text { kosong }\end{array}$ & \\
\hline 3. & F14.1 & $\begin{array}{l}\text { Masyarakat di } \\
\text { lingkungan } \\
\text { tempat tinggal } \\
\text { saya } \\
\text { memberikan } \\
\text { contoh yang } \\
\text { baik pada } \\
\text { anak-anak } \\
\text { usia sekolah } \\
\text { untuk tidak } \\
\text { melakukan } \\
\text { perbuatan } \\
\text { tercela }\end{array}$ & 0,672 \\
\hline 4. & F14.2 & $\begin{array}{l}\text { Masyarakat di } \\
\text { lingkungan } \\
\text { tempat tinggal } \\
\text { saya secara } \\
\text { tegas } \\
\text { melarang } \\
\text { kegiatan yang } \\
\text { dapat } \\
\text { mengganggu } \\
\text { belajar anak- } \\
\text { anak }\end{array}$ & 0,635 \\
\hline
\end{tabular}

Berdasarkan tabel 5 di atas diketahui bahwa faktor 3 yang terbentuk terdiri dari 4 (empat) item pernyataan. Dimana, item pernyataan Saya memanfaatkan perpustakaan untuk membaca buku pada saat jam pelajaran kosong memiliki nilai koefisien faktor tertinggi, yaitu 0,737. Sedangkan, item pernyataan Saya belajar kelompok di rumah teman setelah pulang sekolah memiliki nilai koefisien faktor terendah, yaitu 0,572.

\section{Faktor 4: Alat Pelajaran}

Berdasarkan hasil analisis faktor, maka diperoleh faktor 4 yang selanjutnya diberi identitas alat pelajaran. Faktor yang terbentuk dari pernyataan-pernyataan pendukung dominan yang membentuk faktor 4 tergambar pada tabel sebagai berikut:

Tabel 6. Hasil Analisis Faktor 4

\begin{tabular}{|c|c|l|c|}
\hline $\begin{array}{c}\text { N } \\
\mathbf{0}\end{array}$ & Kode & Pernyataan & $\begin{array}{l}\text { Koefisien } \\
\text { Faktor }\end{array}$ \\
\hline 1. & F9.2 & $\begin{array}{l}\text { Saya } \\
\text { berpakaian } \\
\text { rapi lengkap } \\
\text { dengan } \\
\text { atribut } \\
\text { sekolah }\end{array}$ & 0,618 \\
\hline 2. & F10.2 & $\begin{array}{l}\text { Saya } \\
\text { mempunyai } \\
\text { catatan yang } \\
\text { lengkap dan } \\
\text { rapi }\end{array}$ & 0,677 \\
\hline
\end{tabular}

\begin{tabular}{|l|l|l|l|}
\hline 3. F10.3 & $\begin{array}{l}\text { Saya cepat } \\
\text { meyerap } \\
\text { materi } \\
\text { pelajaran } \\
\text { apabila guru } \\
\text { menggunaka } \\
\text { n media } \\
\text { pembelajaran }\end{array}$ & 0,669 \\
\hline
\end{tabular}

\begin{tabular}{l|l|l|l|}
\hline 4. F12.2 & $\begin{array}{l}\text { Saya mencari } \\
\text { referensi } \\
\text { tambahan } \\
\text { tentang } \\
\text { materi } \\
\text { pelajaran di } \\
\text { internet }\end{array}$ & 0,610 \\
\hline
\end{tabular}

Berdasarkan tabel 6 di atas diketahui bahwa faktor 4 yang terbentuk terdiri dari 4 (empat) item pernyataan. Dimana, item pernyataan Saya mempunyai catatan yang lengkap dan rapi memiliki nilai koefisien faktor tertinggi, yaitu 0,677. Sedangkan, item pernyataan Saya mencari referensi tambahan tentang materi pelajaran di internet memiliki nilai koefisien faktor terendah, yaitu 0,610 . 


\section{E. Faktor 5: Pengertian Orang Tua}

Berdasarkan hasil analisis faktor, maka diperoleh faktor 5 yang selanjutnya diberi identitas pengertian orang tua. Faktor yang terbentuk dari pernyataan-pernyataan pendukung dominan yang membentuk faktor 5 tergambar pada tabel sebagai berikut:

Tabel 7. Hasil Analisis Faktor 5

\begin{tabular}{|c|c|c|c|}
\hline $\begin{array}{l}\mathbf{N} \\
\mathbf{0}\end{array}$ & Kode & Pernyataan & $\begin{array}{c}\text { Koefisien } \\
\text { Faktor }\end{array}$ \\
\hline 1. & F3.1 & $\begin{array}{l}\text { Anggota } \\
\text { keluarga saya } \\
\text { akan } \\
\text { mengecilkan } \\
\text { volume suara } \\
\mathrm{TV} \text { ketika } \\
\text { saya sedang } \\
\text { belajar }\end{array}$ & 0,641 \\
\hline 2. & F5.1 & $\begin{array}{l}\text { Orang tua } \\
\text { saya } \\
\text { mendamping } \\
\text { i ketika } \\
\text { belajar }\end{array}$ & 0,656 \\
\hline 3. & F5.2 & $\begin{array}{l}\text { Orang tua } \\
\text { membantu } \\
\text { saya apabila } \\
\text { mengalami } \\
\text { kesulitan } \\
\text { dalam } \\
\text { memahami } \\
\text { materi } \\
\text { pelajaran }\end{array}$ & 0,722 \\
\hline 4. & F8.4 & $\begin{array}{l}\text { Saya } \\
\text { berdiskusi } \\
\text { dengan } \\
\text { teman-teman } \\
\text { di kelas } \\
\text { untuk } \\
\text { mengerjakan } \\
\text { tugas yang } \\
\text { diberikan } \\
\text { oleh guru }\end{array}$ & 0,561 \\
\hline
\end{tabular}

Berdasarkan tabel 7 di atas diketahui bahwa faktor 5 yang terbentuk terdiri dari 4 (empat) item pernyataan. Dimana, item pernyataan orang tua membantu saya apabila mengalami kesulitan dalam memahami materi pelajaran memiliki nilai koefisien faktor tertinggi, yaitu 0,722. Sedangkan, item pernyataan Saya berdiskusi dengan teman-teman di kelas untuk mengerjakan tugas yang diberikan oleh guru memiliki nilai koefisien faktor terendah, yaitu 0,561 .

\section{F. Faktor 6: Suasana Rumah}

Berdasarkan hasil analisis faktor, maka diperoleh faktor 6 yang selanjutnya diberi identitas suasana rumah. Faktor yang terbentuk dari pernyataan-pernyataan pendukung dominan yang membentuk faktor 6 tergambar pada tabel sebagai berikut:

Tabel 8. Hasil Analisis Faktor 6

\begin{tabular}{|c|l|l|c|}
\hline $\begin{array}{c}\text { N } \\
\text { o }\end{array}$ & Kode & Pernyataan & $\begin{array}{l}\text { Koefisien } \\
\text { Faktor }\end{array}$ \\
\hline 1 & F1.3 & $\begin{array}{l}\text { Orang tua } \\
\text { memberikan } \\
\text { kebebasan } \\
\text { kepada saya } \\
\text { untuk } \\
\text { mengembangk } \\
\text { an bakat dan } \\
\text { potensi yang } \\
\text { dimiliki }\end{array}$ & 0,665 \\
\hline 2 & F3.2 & $\begin{array}{l}\text { Suasana } \\
\text { rumah ribut, } \\
\text { sehingga saya } \\
\text { sulit } \\
\text { berkonsentrasi } \\
\text { dalam belajar }\end{array}$ & \\
\hline
\end{tabular}

Berdasarkan tabel 8 di atas diketahui bahwa faktor 6 yang terbentuk terdiri dari 2 (dua) item 
pernyataan. Dimana, item pernyataan orang tua memberikan kebebasan kepada saya untuk mengembangkan bakat dan potensi yang dimiliki memiliki nilai koefisien faktor tertinggi, yaitu 0,665. Selanjutnya, item pernyataan suasana rumah ribut, sehingga saya sulit berkonsentrasi dalam belajar memiliki nilai koefisien faktor terendah, yaitu 0,598.

\section{G. Faktor 7: Relasi Guru dengan} Siswa

Berdasarkan hasil analisis faktor, maka diperoleh faktor 7 yang selanjutnya diberi identitas relasi guru dengan siswa. Faktor yang terbentuk dari pernyataan-pernyataan pendukung dominan yang membentuk faktor 7 tergambar pada tabel sebagai berikut:

Tabel 9. Hasil Analisis Faktor 7

\begin{tabular}{|l|l|l|c|}
\hline $\begin{array}{l}\mathbf{N} \\
\text { o }\end{array}$ & Kode & Pernyataan & $\begin{array}{l}\text { Koefisien } \\
\text { Faktor }\end{array}$ \\
\hline 1. & F7.1 & $\begin{array}{l}\text { Saya konsultasi } \\
\text { dengan guru } \\
\text { ketika } \\
\text { menghadapi } \\
\text { masalah } \\
\text { pelajaran di } \\
\text { sekolah }\end{array}$ & \\
\hline 2. F7.375 & $\begin{array}{l}\text { Saya malas } \\
\text { bertanya } \\
\text { kepada guru } \\
\text { apabila materi } \\
\text { pelajaran yang } \\
\text { disampaikan } \\
\text { kurang jelas }\end{array}$ \\
\hline 3. F12.1 & $\begin{array}{l}\text { Saya lebih suka } \\
\text { menonton } \\
\text { televisi } \\
\text { daripada belajar }\end{array}$ \\
\hline
\end{tabular}

Berdasarkan tabel 9 di atas diketahui bahwa faktor 7 yang terbentuk terdiri dari 3 (satu) item pernyataan.
Dimana, item pernyataan saya konsultasi dengan guru ketika menghadapi masalah pelajaran di sekolah memiliki nilai koefisien faktor tertinggi, yaitu 0,675. Sedangkan, item pernyataan saya malas bertanya kepada guru apabila materi pelajaran yang disampaikan kurang jelas memiliki nilai koefisien faktor terendah, yaitu 0,637.

\section{H. Faktor 8: Disiplin Sekolah}

Berdasarkan hasil analisis faktor, maka diperoleh faktor 8 yang selanjutnya diberi identitas disiplin sekolah. Faktor yang terbentuk dari pernyataan-pernyataan pendukung dominan yang membentuk faktor 8 tergambar pada tabel sebagai berikut:

Tabel 10. Hasil Analisis Faktor 8

\begin{tabular}{|c|c|l|c|}
\hline $\begin{array}{c}\mathbf{N} \\
\mathbf{o}\end{array}$ & Kode & Pernyataan & $\begin{array}{l}\text { Koefisien } \\
\text { Faktor }\end{array}$ \\
\hline 1. & F9.1 & $\begin{array}{l}\text { Saya } \\
\text { melakukan } \\
\text { piket kelas } \\
\text { sesuai } \\
\text { dengan } \\
\text { jadwal yang } \\
\text { telah } \\
\text { ditetapkan }\end{array}$ & 0,769 \\
\hline 2. & F9.3 & $\begin{array}{l}\text { Saya hadir di } \\
\text { sekolah } \\
\text { sebelum bel } \\
\text { masuk bunyi }\end{array}$ & 0,758 \\
\hline
\end{tabular}

Berdasarkan tabel 10 di atas diketahui bahwa faktor 8 yang terbentuk terdiri dari 2 (dua) item pernyataan. Dimana, item pernyataan saya melakukan piket kelas sesuai dengan jadwal yang telah ditetapkan memiliki nilai koefisien faktor tertinggi, yaitu 0,769. Sedangkan, item pernyataan Saya hadir di sekolah 
sebelum bel masuk bunyi memiliki nilai koefisien faktor terendah, yaitu 0,758 .

\section{Faktor 9: Teman Bergaul}

Berdasarkan hasil analisis faktor, maka diperoleh faktor 9 yang selanjutnya diberi identitas teman bergaul, yang mencakup 2 item pernyataan. Faktor yang terbentuk dari pernyataan-pernyataan pendukung dominan yang membentuk faktor 9 tergambar pada tabel sebagai berikut:

Tabel 11. Hasil Analisis Faktor 9

\begin{tabular}{|l|l|l|c|}
\hline $\begin{array}{l}\mathbf{N} \\
\mathbf{0}\end{array}$ & Kode & Pernyataan & $\begin{array}{c}\text { Koefisien } \\
\text { Faktor }\end{array}$ \\
\hline 1 & F8.2 & $\begin{array}{l}\text { Saya } \\
\text { menciptakan } \\
\text { hubungan } \\
\text { yang harmonis } \\
\text { dengan teman- } \\
\text { teman di } \\
\text { sekolah }\end{array}$ & 0,644 \\
\hline 2 & F13.2 & $\begin{array}{l}\text { Teman-teman } \\
\text { membantu } \\
\text { saya ketika } \\
\text { mengalami } \\
\text { kesulitan } \\
\text { belajar }\end{array}$ & 0,700 \\
\hline
\end{tabular}

Berdasarkan tabel 11 di atas diketahui bahwa faktor 9 yang terbentuk terdiri dari 2 (dua) item pernyataan. Dimana, item pernyataan teman-teman membantu saya ketika mengalami kesulitan belajar memiliki nilai koefisien faktor tertinggi, yaitu 0,700 . Sedangkan, item pernyataan orang saya menciptakan hubungan yang harmonis dengan teman-teman di sekolah memiliki nilai koefisien faktor terendah, yaitu 0,644 .

\section{J. Faktor 10: Keadaan Ekonomi Orang Tua \\ Berdasarkan hasil analisis faktor, maka diperoleh faktor 10 yang selanjutnya diberi identitas keadaan ekonomi orang tua. Faktor yang}

terbentuk dari pernyataan-pernyataan pendukung dominan yang membentuk faktor 10 tergambar pada tabel sebagai berikut:

Tabel 12. Hasil Analisis Faktor 10

\begin{tabular}{|l|l|l|c|}
\hline $\begin{array}{l}\mathbf{N} \\
\mathbf{o}\end{array}$ & Kode & Pernyataan & $\begin{array}{c}\text { Koefisien } \\
\text { Faktor }\end{array}$ \\
\hline 1 & F3.3 & $\begin{array}{l}\text { Saya } \\
\text { mempunyai } \\
\text { ruang belajar } \\
\text { yang nyaman }\end{array}$ & 0,771 \\
\hline 2 & F4.1 & $\begin{array}{l}\text { Orang tua } \\
\text { memenuhi } \\
\text { semua } \\
\text { perlengkapan } \\
\text { belajar saya }\end{array}$ & 0,633 \\
\hline
\end{tabular}

Berdasarkan tabel 12 di atas diketahui bahwa faktor 10 yang terbentuk terdiri dari 2 (satu) item pernyataan. Dimana, item pernyataan saya mempunyai ruang belajar yang nyaman memiliki nilai koefisien faktor tertinggi, yaitu 0,771 . Sedangkan, item pernyataan Orang tua memenuhi semua perlengkapan belajar saya memiliki nilai koefisien faktor terendah, yaitu 0,633.

\section{SIMPULAN}

Berdasarkan hasil penelitian yang peneliti peroleh maka dapat diambil kesimpulan sebagai berikut:

1. Variabel lingkungan belajar berada pada kategori cukup dengan rata-rata 3,91 dan Tingkat Capaian Responden (TCR) sebesar 78,26.

2. Terdapat 10 (sepuluh) faktor dominan yang mempengaruhi lingkungan belajar siswa, yaitu:

a. Faktor 1 yang diberi metode mengajar, yang terdiri dari item pernyataan F6.1, F6.2, F6.3, F7.2, dan F7.4. 
b. Faktor 2 yang diberi identitas relasi antara anggota keluarga, yang terdiri dari item pernyataan F2.2, F2.3, dan F14.3.

c. Faktor 3 yang diberi identitas bentuk kehidupan masyarakat, yang terdiri dari item pernyataan F8.3, F10.1, F14.1, dan F14.2.

d. Faktor 4 yang diberi identitas alat pelajaran, yang terdiri dari item pernyataan F9.2, F10.2, F10.3, dan F12.2.

e. Faktor 5 yang diberi identitas pengertian orang tua, yang terdiri dari item pernyataan F3.1, F5.1, F5.2, dan F8.4.

f. Faktor 6 yang diberi identitas suasana rumah, yang terdiri dari item pernyataan F1.3 dan F3.2.

g. Faktor 7 yang diberi identitas relasi guru dengan siswa, yang terdiri dari item pernyataan F7.1, F7.3, dan F12.1.

h. Faktor 8 yang diberi identitas disiplin sekolah, yang terdiri dari item pernyataan F9.1, dan F9.3.

i. Faktor 9 yang diberi identitas teman bergaul, yang terdiri dari item pernyataan F8.2 dan F13.2.

j. Faktor 10 yang diberi identitas keadaan ekonomi orang tua, yang terdiri dari item pernyataan F3.3 dan F4.1.

Berdasarkan hasil penelitian yang peneliti peroleh, maka disarankan kepada:

1. Siswa

Siswa hendaknya menciptakan lingkungan belajar yang nyaman dan menyenangkan, sehingga peningkatan hasil belajar dapat tercapai.

2. Guru

Guru hendaknya lebih meningkatkan kompetensinya dan selalu membimbing serta membina siswanya agar berkembang semaksimal mungkin, sehingga peningkatan hasil belajar dapat terwujud.

3. Orang Tua

Orang tua hendaknya memiliki kesadaran yang besar dalam memperhatikan fasilitas belajar anak dan perhatian terhadap pendidikan anak, sehingga keberhasilan anak dalam belajar tercapai.

4. Sekolah

Sekolah hendaknya menciptakan lingkungan belajar yang kondusif, sehingga peningkatan kualitas lulusan dapat terwujud.

\section{DAFTAR PUSTAKA}

Aini, P. N., \& Taman, A. (2012). Pengaruh Kemandirian Belajar dan Lingkungan Belajar Siswa Terhadap Prestasi Belajar Akuntansi Siswa Kelas XI IPS SMA Negeri 1 Sewon Bantul Tahun Ajaran 2010/2011. Jurnal Pendidikan Akuntansi Indonesia, $X(1), 66-77$.

Akhirmen. (2012). Statistika 1 (Teori dan Aplikasi). Padang: FE UNP.

Arikunto, S. (2014). Prosedur Penelitian: Suatu Pendekatan Praktek. Jakarta: PT Rineka Cipta.

Aunurrahman. (2011). Belajar dan Pembelajaran. Bandung: Alfabeta. 
Baharuddin dan Wahyuni, N.E. (2010). Teori Belajar dan Pembelajaran. Yogyakarta: Ar-Ruzz Media.

Dalyono. (2009). Psikologi Pendidikan. Jakarta: Rineka Cipta.

Fitriani, A. (2011). "Pengaruh Motivasi dan Lingkungan Belajar Terhadap Prestasi Belajar Mata Pelajaran Ekonomi Pada Siswa Kelas VIII SMP N 5 Purwodadi”. Skripsi tidak diterbitkan. Semarang: Universitas Negeri Semarang.

Hamalik, O. (2013). Proses Belajar Mengajar. Jakarta: Bumi Aksara.

Hasbullah. (2013). Dasar-Dasar Ilmu

Pendidikan. Jakarta:

Rajagrafindo Persada.

Idris. (2010). Aplikasi Model Analisis

Data Kuantitatif Dengan

Program SPSS. Padang: UNP.

Krathwohl, R, D, Bloom, S.B, and

Masia, B,B. (1971).

Taxonomy of Educational

Objectives: The Classification of Educational Goals. New York: David McKay Company, Inc.

Lubis, S. (2011). Metodologi Penelitian Pendidikan.

Padang: Sukabina Press.

Mariyana, R. (2010). Pengelolaan Lingkungan Belajar. Jakarta: Kencana Prenada Media Group.

Purwanto. (2013). Evaluasi Hasil Belajar. Yogyakarta: Pustaka Pelajar.

Riduwan dan Kuncoro, A.E. (2012). Cara Menggunakan dan
Memaknai Path Analysis: Analisis Jalur. Bandung: Alfabeta.

Riduwan. (2013). Belajar Mudah Penelitian Untuk GuruKaryawan dan Peneliti Pemula. Bandung: Alfabeta.

Rusman. (2012). Belajar dan Pembelajaran Berbasis Komputer: Mengembangkan Profesionalisme Guru Abad 21. Bandung: Alfabeta.

Sadulloh, U. (2010). Pedagogik (Ilmu Pendidik). Bandung: Alfabeta.

Slameto. (2010). Belajar dan FaktorFaktor yang Mempengaruhi. Jakarta: Rineka Cipta.

Sugiyono. (2015). Metode Penelitian Pendidikan: Pendekatan Kuantitatif, Kualitatif, dan $R \& D$. Bandung: Alfabeta.

Undang-Undang Sistem Pendidikan Nasional (UU RI No. 20 Tahun 2003). Jakarta: Sinar Grafika.

Uno, B, H. (2007). Teori Motivasi dan Pengukurannya: Analisis di Bidang Pendidikan. Jakarta: PT Bumi Aksara.

Winarno, B. (2012). "Pengaruh Lingkungan Belajar dan Motivasi Berprestasi Terhadap Hasil Belajar Siswa Kompetensi Keahlian Teknik Otomasi Industri Di Sekolah Menengah Kejuruan Negeri 2 Depok Yogyakarta". Skripsi tidak diterbitkan. Yogyakarta: Universitas Negeri Yogyakarta.

Winkel, W.S. (2007). Psikologi Pengajaran: Yogyakarta: Media Abadi. 